\title{
GoRETity József
}

\section{Mit fordítsunk?}

A kortárs orosz irodalom magyarországi recepciója egy műfordító szemével

\section{Elméleti megfontolások}

Kétségtelen, hogy a külföldi irodalom befogadása a saját nemzeti kultúrába mindig fontos szerepet tölt be a két kultúra - az átadó és a befogadó - kölcsönös megértésében. Természetesen minden esetben felmerül annak kérdése, hogy mennyire tud az anyanyelvre fordított külföldi irodalmi mű a saját, nemzeti kultúra elválaszthatatlan részévé válni. Kell-e a fordítónak demonstrálnia, hogy idegen nyelven született eredeti müről van szó, vagy éppen ellenkezőleg, azt a látszatot kell keltenie, hogy az adott mü az anyanyelvén született, következésképpen minden akadály nélkül beleíródhat a saját nemzeti kultúrába? ${ }^{1}$ Melyik stratégia ad esélyt az eredeti münek arra, hogy erőteljesebben hasson a célközönségre? E kérdésre valószínűleg nincs egyértelmű válasz - a befogadó irodalomban nagy valószínűséggel lehet példákat találni egyik vagy másik variációra is.

A fordítandó művek megválasztásának elvével kapcsolatban Itamar Even-Zohar a következőket írja: „Nyilvánvaló tehát, hogy a fordítandó művek megválasztásának az elvét a helyi, saját irodalmi rendszert irányító aktuális állapot határozza meg: a szövegeket aszerint választják ki, hogy mennyire összeegyeztethetők a célnyelvi irodalmon belüli új megközelítésmódokkal és az általuk betöltött feltételezett újító szereppel.”2 Elfogadva Even-Zohar álláspontját, arra a következtetésre juthatunk, hogy a befogadás elvében két alapvető, egymással ellentétes irányú mechanizmus múködik.

a) A hiánypótlás. Ebben az esetben arról van szó, hogy a célnyelvi irodalomból nyilvánvalóan hiányzik olyan irodalmi mü - esetleg valamely irodalmi mü képviselte egész müfaj -, amelyet a forrásnyelvi irodalomban vélnek felfedezni, és azért fordítják le az adott művet, hogy a saját, nemzeti irodalomban ezt a hiányt megszüntessék.

Amikor Katona József megjelentette a Mi az oka, hogy Magyarországban a játékszíni költömesterség lábra nem tud kapni? (1821) címü híres röpiratát, nyilvánvaló volt, hogy a magyar színházi élet fejlődésének egyik gátja a közönség ízlését kiszolgálni képes, játszható magyar színdarabok hiánya. Nem lévén eredeti magyar nyelvü, közönségszórakoztató rémdráma, németből kellett fordítani ilyeneket: maga Katona József is készített még 1812-ben egy efféle átiratot, A borzasztó torony, vagyis a gonosz talált gyermek címü öt felvonásos müvet egy német lovagregényből. Amikor 1866-ban Bérczy Károly

\footnotetext{
${ }^{1}$ A müfordítással szemben támasztott ilyesfajta követelményről a német filozófus, Friedrich Schleiermacher ír a műfordítás különféle módszereiről szóló nevezetes esszéjében: Friedrich ScHLEIERMACHER, Über die verschiedenen Methoden des Übersetzens = F. Sch., Sämtliche Werke, Berlin, 1838, II, 207-245.

${ }^{2}$ Itamar Even-Zohar, A fordítás helye az irodalmi (több)rendszer elméletében, ford. JANovits Enikö Mária = Kettős megvilágítás, szerk. Józan Ildikó, Jeney Éva, Hajdu Péter, Bp., Balassi, 2007, 211.
} 
fordításában megjelent magyarul a teljes Jevgenyij Anyegin, a magyar irodalomban valóságos versesregény-áradat indult el. A magyar irodalmi életben addig kevéssé ismert müfaj szinte példátlan népszerűségre tett szert, és a Puskin-mű hatására még a két világháború között is születtek verses regények. ${ }^{3}$

b) A ráismerés. Ebben az esetben arról van szó, hogy a célnyelvi irodalomban van valamely mü (vagy vannak olyan müvek), amely (amelyek) az adott kultúrában akutnak mondható társadalmi vagy esztétikai problémát fejez(nek) ki. Ha a célnyelvi irodalom a forrásnyelvi irodalomban hasonló problémával foglalkozó müre lel, a célnyelvi irodalom számára érdekessé válhat, miként tárgyalja ugyanazt a problémát a forrásnyelvi irodalom: a célnyelvi irodalom mintegy „ráismer” a forrásnyelvi irodalomban a hasonlóságra, és „kíváncsivá” lesz a hasonlóság mértékére, illetve a különbözőségekre. A magyar és az orosz irodalom vonatkozásában ilyen jelenséget figyelhetünk meg a 19. század második felében, amikor német és francia közvetítéssel eljutnak Magyarországra és népszerüvé válnak Turgenyev művei. Turgenyev regényeiben és elbeszéléseiben a magyar olvasóközönség mindenekelött a nemesi udvarházak életének kettősségét érzékelte: azt a helyzetet, hogy egyfelől minden társadalmi-gazdasági ok megvolt szükségszerü pusztulásukhoz, másfelől viszont a nemesi udvarházak pusztulása egy egész kultúra eltűnését is jelentette. A probléma Magyarországon is ismert és akut volt, amelyet talán Gyulai Pál rögzített legérzékletesebben az Egy régi udvarház utolsó gazdája (1857) címü kisregényében. A Gyulai-mű után a magyar irodalom Turgenyev müveiben ugyanerre a problémára „ismert rá” és fogadta be a fordításukat. Egyáltalán nem véletlen, hogy Turgenyev egyik leginkább e problémával foglalkozó regényéről, a Nemesi fészekről a magyar nyelvű megjelenése kapcsán éppen Gyulai Pál írt ismertetőt. ${ }^{4}$

Előfordul - viszonylag ritkán - az ilyesfajta befogadásnak és irodalmi hatásnak egészen közvetlen módja is. A magyar posztmodern irodalom egyik legjelentősebb művében, a sok vonatkozásban összegző jellegü Harmonia colestis című regényben Esterházy Péter szinte szó szerint megidézi az orosz posztmodern egyik jellegzetes képviselője, Dmitrij Galkovszkij Végtelen zsákutca című munkájának egyik fejezetét. ${ }^{5}$ Galkovszkij műve ugyanúgy szintézisteremtő szándékkal megírt, hibrid műfajú posztmodern alkotás, mint az Esterházyé, és mindkettőre érvényes az a megállapítás, amelyet Orbán Ottó tett a Harmonis ceelestis kapcsán: „Esterházy úgy dob ki mindent az ajtón, ami a hagyományos regény sajátja, hogy az ablakon át visszacsempészi őket, nem ravaszságból, hanem bölcsességből - tudja, hogy az újítás értéke mindig viszonylagos, regényének szövege attól több bravúros mondatok füzérénél, hogy a klasszikus nagyregény árnyéka vetül rájuk." ${ }^{6}$

\footnotetext{
${ }^{3}$ Erről részletesen lásd ImRe László, A magyar verses regény, Bp., Akadémiai, 1990.

${ }^{4}$ Gyulai Pál, A nemes fészek, Szépirodalmi Figyelö, 1862. 2. kötet, 20. szám, 315-316.

${ }^{5}$ Vö. Esterházy Péter, Harmonia coelestis, Bp., Magvető, 2000, 138. (147. mondat); Dmitrij GalkovszkiJ, Végtelen zsákutca, 152. széljegyzet a 104. ponthoz, ford. Goretiтy József, Jelenkor, 1997/7-8, 724.

${ }^{6}$ Orbán Ottó, Boreász sörénye, Bp., Magvető, 2001, 236.
} 
Bármilyen módon is történik meg a befogadás, a fordítás csak akkor nem avul el, akkor lesz képes hosszú időn át fennmaradni, ha a fordított szöveg a célnyelvi irodalom elválaszthatatlan részévé válik, ha a befogadó nemzeti irodalom olyan alkotásaként mutatkozik meg, amelyik valódi, megtermékenyítően ható költői nyelvvel rendelkezik. Olyannal, amelyikről Henri Meschonnic azt állítja, hogy csak a forrásnyelvi irodalom rendelkezik: tevékeny, alakító nyelvvel, szemben a fordításnak, a célnyelvnek „,ismert, tudott, passzív, már átalakított nyelv"-ével. ${ }^{7}$ Vagyis ha a fordítás is olyan müvészeti alkotássá tud válni, amelyik képes a kifejezhetetlen kifejezésére, a Wolfgang Iser-féle értelemben vett imaginárius megsejtetésére. ${ }^{8}$

\section{Történeti vázlat}

Az orosz irodalom magyarországi recepciója körülbelül kétszáz évet ölel fel - olyan időkig nyúlik vissza, amikor orosz irodalmi művek még nem is jelentek meg magyarul. Az első magyarországi híradás az orosz irodalomról Horváth Istvántól származik, aki Karamzin nagyszabású, az orosz irodalmi nyelvet megújító történelmi művéről, Az orosz állam történetéről jelentetett meg ismertetést. ${ }^{9}$ Ugyancsak az első lépésekhez tartozik Toldy Ferenc orosz irodalomról szóló, 1834-es ismertetője, ${ }^{10}$ amelyben - anélkül, hogy magát a müvet ismerte volna - említést tett Puskin Anyeginjéről is. Az Anyegin- és Puskin-kultuszról fentebb már említést tettünk, és nyilvánvaló, hogy ez a kultusz elsősorban Bérczy Károly Anyegin-fordításának volt köszönhető, de nagymértékben hozzájárult Jókai Mór dekabristákról szóló regénye, a Szabadság a hó alatt (1879) is, amely azzal erősítette a kultuszt, hogy párhuzamot alakított ki Puskin és Petőfi romantikus alakjai között. ${ }^{11}$ Az 1850 -es években ismerkedhetett meg a magyar olvasóközönség Puskin, Lermontov, Gogol és Turgenyev prózai műveivel, és Turgenyev - a korábban már említett okok miatt - ekkortól vált az egyik legnépszerübb orosz íróvá. Tolsztoj és Dosztojevszkij recepciója némiképp még váratott magára, az ö írásaik (Tolsztojtól a Háború és béke, valamint az Anna Karenina, Dosztojevszkijtől pedig a Bün és bünhődés, amelyet sokáig az egyetlen jó regényének ítéltek) majd csak az 1870-80-as években jutottak el a magyar olvasóközönséghez - németből és franciából fordítva. ${ }^{12}$

\footnotetext{
${ }^{7}$ Henri Meschonnic, Fordításpoétika, ford. HaAs Lídia, JózAn Ildikó = Kettős megvilágítás, i. m., 404.

${ }^{8}$ Lásd Wolfgang Iser, A fiktív és az imaginárius, ford. Molnár Gábor Tamás, Bp., Osiris, 2001.

${ }^{9}$ Horváth István, Geschichte des Russischen Reiches, Tudományos Gyüjtemény, 1826. 2. kötet, 104-109.

${ }^{10}$ Toldy Ferenc, A muszka irodalom jelen állapotja, Tudománytár, 1834. IV. kötet, 65-82.

${ }^{11}$ A Jókai-regény Puskin-képéről részletesebben lásd Kalavszky Zsófia, A megfordított arc, Új Forrás, 2005/3, 23-32.

${ }^{12}$ A klasszikus orosz irodalom 19. századi magyarországi recepciójáról lásd bővebben: ZöLDHELYI Zsuzsa, Az orosz irodalom magyar fogadtatása a XIX. században = Bevezetés a XIX. századi orosz irodalom történetébe, szerk. Kroó Katalin, Bp., Bölcsész Konzorcium, 2006, II, 826-851.
} 
A klasszikus orosz irodalom magyarországi befogadásában nagy szerepet játszott - jellemző módon - egy franciából fordított, 1908-ban megjelent igényes szakmunka, Vogüé orosz regényről írott műve, amely nemcsak amiatt figyelemre méltó alkotás, mert a mai napig érvényes megállapításokat és értékítéleteket közöl a klasszikus orosz irodalomról, hanem amiatt is, mert információval szolgált a legújabb orosz szerzőkröl (például a fiatal Gorkijról) is. ${ }^{13}$

A 20. század elején a klasszikus orosz irodalom mellett nagy érdeklődés mutatkozott a kortárs orosz irodalom iránt is. A nyugatosok körében nagy népszerüségnek örvendett Csehov müvészete (Kosztolányi Dezső a Három nővért, Tóth Árpád a Cseresznyéskertet fordította le magyarra),${ }^{14}$ de a századelőn megjelentek magyarul a legújabb, orosz szimbolista szerzők (Dmitrij Merezskovszkij, Fjodor Szologub, Valerij Brjuszov, Andrej Belij, Alekszej Remizov) művei is. Örvendetes tény, hogy az 1910-20-as években fellépett egy olyan fordítónemzedék, amelynek tagjai (Peterdi István, Pásztor Árpád, Haiman Hugó, Görög Imre) már nem francia vagy német közvetítőnyelven keresztül, hanem közvetlenül oroszból fordítottak, ami nyilvánvalóan kihatott a fordítások minőségére, és mindenképpen pozitívan befolyásolta a befogadás eredményességét is.

A 20. század második felében a magyar fordítók heroikus munkát végeztek el: gyakorlatilag lefordították a teljes klasszikus orosz irodalmat (Puskin, Lermontov, Gogol, Goncsarov, Turgenyev, Tolsztoj, Dosztojevszkij, Csehov minden jelentős müvét), különféle költői antológiákban megjelentették az orosz klasszikus líra remekeit, a régi orosz kultúra és irodalom több jeles alkotását (mint például az Ének Igor hadárólt, Avvakum protopópa Önéletírását), a 19. századi orosz filozófia több jeles képviselőjének (Csaadajevnek, Belinszkijnek, Herzennek, Dobroljubovnak, Csernisevszkijnek) munkáit. Mindemellett fordították és nagy példányszámban adták ki a kortárs szovjet irodalmat, annak sikerültebb és kevéssé sikerültebb, sematikus szocialista realista írásait is.

Azt hiszem, e vázlatos történeti áttekintés is jól érzékelteti, hogy az orosz és a magyar irodalom között kétszáz év óta szoros kapcsolat alakult ki, és az orosz irodalom magyarországi recepciója meglehetősen komoly és mély volt: $s$ az maradt a legújabb időkben, az utóbbi 30-35 évben is. Meg kell jegyeznem ugyanakkor, hogy az orosz irodalom magyarországi befogadásában a két világháború közötti időszaktól kezdődően nemcsak esztétikai, hanem gyakran társadalmi-politikai, pontosabban kultúrpolitikai szempontok is közrejátszottak, és ez érvényes maradt a legutóbbi időkre is.

\footnotetext{
${ }^{13}$ E. M. de VogüÉ, Az orosz regény, ford. Huszár Imre, Bp., Magyar Tudományos Akadémia, 1908, I-II.

${ }^{14}$ A Csehov-drámák magyar fordításainak nyelvi-stilisztikai koncepciójában bekövetkezett történeti változásokról lásd Cs. JónÁs Erzsébet, Csehov-drámák magyarul: fordításstilisztikai jegyzetek = Közelítések - Közvetitések: Anton Pavlovics Csehov, szerk. Regéczi Ildikó, Debrecen, Didakt, 2011, 132-157.
} 


\section{Az orosz irodalom magyar recepciója 1985-töl}

Az orosz irodalom magyarországi recepciójának 1985-től terjedő időszakát feltételesen négy nagyobb időegységre lehet osztani, amelyeknek mindegyike meghatározott sajátosságokkal bír: 1. Az 1980-as évek második fele: a „peresztrojka” és a "glasznoszty” hatása; 2. Az 1990-es évek: a majdnem teljes hallgatás időszaka; 3. A 2000-es évek: a posztmodern irodalom befogadásának dominanciája; 4. A 2010-es évek: az „újrealizmus" irodalmának recepciója.

\section{1, Az 1980-as évek második fele: a "peresztrojka" és a "glasznoszty" hatása}

Mint ismeretes, az orosz (szovjet) kultúr- és irodalompolitikában a „peresztrojka” és a „glasznoszty” új politikai irányának köszönhetően jelentős változások következtek be, olyanok, amelyek elképzelhetetlenek voltak a brezsnyevi „pangás” időszakában. E változások eredményeképpen a gorbacsovi Szovjetunióban megjelenhettek olyan irodalmi müvek, amelyeket a sztálini és brezsnyevi korszakban „dekadenseknek”, vagyis lényegében "kártékonyaknak” volt szokás tartani. E körbe tartozott mindenekelött az orosz „ezüstkor” irodalma - a szimbolisták, az akmeisták és az avantgárd képviselőinek művei. Az ezekhez az irányzatokhoz tartozó szerzők életműve, annak ellenére, hogy kiadásukban történt némi elmozdulás a Hruscsov-féle „olvadás” időszakában, lényegében ismeretlen maradt az orosz olvasóközönség széles rétegei előtt (legfeljebb szamizdatból és tamizdatból válhatott ismertté a bátrabb, másként gondolkodó értelmiségiek számára). E szerzők műveit nem adták ki, az iskolában és a felsőoktatásban nem tanították, az irodalomtörténeti munkákban vagy egyáltalán nem említették meg őket, vagy ha mégis, akkor csak erőteljes elítéléssel, időnként majdhogynem szitokszavak kíséretében. Mindez ahhoz vezetett, hogy az orosz irodalomtörténetből nem egyszerüen csak egyes szerzőket, hanem egész irodalmi irányzatokat „húztak ki”. Amikor pedig a „peresztrojka” kultúrpolitikája mintegy „visszaadta” ezeket a szerzőket és műveiket az olvasóközönségnek, az „ezüstkor” irodalma - eszméi, poétikai eszközei, elbeszélői módszerei stb. - nem egyszerüen csak kilépett az ismeretlenség homályából, hanem mint új és modern irodalom tárulkozott fel. Lényegében az a furcsa helyzet állt elő, hogy a 70-80 évvel korábban írott müveket az orosz olvasó „kortárs” művekként olvasta, ami természetesen nagyban kihatott az 1980-as évek végének kortárs irodalmi befogadására is. Olyan szerzőkről és művekről van szó (a teljesség igénye nélkül), mint Dmitrij Merezskovszkij Krisztus és Antikrisztus címü regénytrilógiája, Fjodor Szologub regényei (Nehéz álmok, Undok ördög, Teremtett legenda), Alekszej Remizov kisregényei (Testvérek a keresztben, A tó, Az óra), Andrej Belij regényei (Az ezüst galamb, Pétervár, Keresztrefeszités), Andrej Platonov regényei és kisregényei (Csevengur, Munkagödör, Az ifjúság tengere, Dzsan), Jevgenyij Zamjatyin elhíresült antiutópiája, a Mi, Mihail Bulgakov 1920-as években írott kisregényei (Kutyasziv, Végzetes tojások, Ördögösdi), Konsztantyin Vaginov kisregényei (Kecskeének, Harpagoniáda, Munkák és napok), Borisz Pilnyak írásai (Meztelen év, A kiolthatatlan 
hold elbeszélése), Mihail Zoscsenko önéletrajzi regénye, a Napfelkelte elött, Velimir Hlebnyikov és Danyiil Harmsz írásai, stb.

A peresztrojka idején megjelentetett, korábban politikai okok miatt betiltott müvek második nagy csoportját az úgynevezett „szovjetellenes” könyvek tették ki. E körbe többek között olyan müvek tartoztak, mint Borisz Paszternak Zsivago doktora, Anatolij Ribakov Az Arbat gyermekei címü regénye, valamint a GULAG-ról szóló müvek: Varlam Salamov Kolimai elbeszélései, Alekszandr Szolzsenyicin müvei (A GULAG szigetvilág, A pokol tornáca, Rákosztály), Jevgenyija Ginzburg Meredek út címü müve. Megjelenhettek végre az orosz emigráns irodalom legjelentősebb müvei, mindenekelött Vladimir Nabokov regényei, M. Agejev Kokainos regénye, Nyina Berberova Kiemelés tölem címü munkája, Szergej Dovlatov és Juz Aleskovszkij kisregényei, Vlagyimir Vojnovics Ivan Csonkin közlegény élete és különös kalandjai címü szatirikus regénye, Szasa Szokolov Bolondok iskolája címü kisregénye, stb. ${ }^{15}$

A „fejlett szocializmus” időszakában a korabeli kultúrpolitikának megfelelően - annak ellenére, hogy a magyar kultúrpolitika jóval „puhább” volt, mint a szovjet - csak azok az orosz (szovjet) irodalmi müvek jelenhettek meg magyarul, amelyeknek létezett hivatalos kiadása a Szovjetunióban. Ennek következményeként a Szovjetunióban betiltott orosz (szovjet) müvek Magyarországon is tiltólistára kerültek. Amikor azonban a „peresztrojka” és a „glasznoszty” hatására a Szovjetunióban megjelenhettek a fentebb felsorolt, korábban tiltott müvek, Magyarországon is megnyílt a lehetőség a magyar nyelvü kiadásuk elött. Ily módon a magyar olvasóközönség ebben az időszakban megismerkedhetett a felsorolt szerzőkkel és müveikkel - gyakorlatilag az orosz kiadásukkal párhuzamosan (annál is inkább, mert jó néhány münek létezett már magyar fordítása, éppen csak elfeküdtek a szerkesztőségek iratszekrényeiben vagy a fordítók íróasztalfiókjában).

E folyamatban fontos szerepet játszott két irodalmi folyóirat, a Szovjet Irodalom és a Nagyvilág, valamint az akkor még állami tulajdonban lévő Európa Könyvkiadó, amely hagyományosan külföldi irodalom kiadásával foglalkozott. Az 1980-as évek végén, amikor a szocialista éra a végéhez közeledett, létrejöttek magánkiadók is, amelyek felismerve a konjunktúrát - előszeretettel adták ki a korábban tiltottnak számító orosz (szovjet) irodalmat: gyakran a szerző tudta és hozzájárulása, a szerzői jogok rendezése nélkül, minősíthetetlen fordításban, rossz minőségü papíron, az első olvasáskor lapjaira hulló könyvben. Ez történt például A GULAG szigetvilág címü Szolzsenyicin-művel 1989-ben, amikor egy bizonyos - egyébként a könyvpiacról hamarosan eltünő - Új Idők nevű magánkiadó megjelentette a művet magyarul, annak a magyar fordításnak alapján, amely 1975-1976-ban jelent meg Münchenben, elképesztően gyenge fordításban, jelentős szövegkihagyásokkal. A korabeli viszonyokra jellemző, hogy mindez megtehető volt, az Új Idők ráadásul komoly jövedelmet realizálhatott a kalózkiadásból.

\footnotetext{
${ }^{15}$ Az elhallgatott, majd a „peresztrojka” idején nyilvánosságra hozott irodalmi művekkel kapcsolatban lásd a Helikon 1993/2-3 tematikus számát, amelynek sokatmondó a címe is: Elsikkasztott orosz irodalom.
} 
Az Európa Könyvkiadó, amely betartotta a könyvkiadás elemi szabályait, és kiváló fordításban és könyvminőségben adta a ki a művet (három kötetben), „elkésett” a kiadással, néhány héttel az Új Idők kétkötetes GULAGja után jelent csak meg, és nem kis anyagi veszteséget volt kénytelen elviselni a könyvpiacon.

Egészen másként alakult a sorsa Borisz Paszternak Zsivago doktor című regénye első magyar kiadásának. A könyvet 1988-ban szintén egy magánkiadó, az Árkádia adta ki szégyenletesen gyenge fordításban, silány minőségü könyvben, de a nagy érdeklődésre való tekintettel és nyilván a nagy anyagi haszon reményében hatalmas példányszámban. Amikor azonban a széles olvasóközönség számára kiderült, hogy Paszternak regénye egyáltalán nem az a szórakoztató (vagyis szirupos, ál-szentimentális) regény, mint amilyennek az azonos címü népszerü amerikai film alapján (a sármos Omar Shariffal a föszerepben) képzelte, akkor a könyvet nem vásárolták tovább, mondván, hogy ez is csak ugyanolyan unalmas és nehéz orosz (szovjet) iromány, mint a többi. Mindennek az lett az eredménye, hogy bár a könyvet azóta időről időre újra kiadják (ugyanabban a gyenge fordításban, de jobb könyvminőségben), Borisz Paszternak Zsivago doktora nem tudta elfoglalni a magyar irodalmi köztudatban a hozzá méltó helyet, nem kapta meg az őt megillető értékelést és elismerést.

\section{2, Az 1990-es évek: a majdnem teljes hallgatás időszaka}

A magyarországi rendszerváltást követően, az 1989-1990-től kezdődő időszakban az orosz és szovjet irodalomhoz való viszony jelentősen megváltozott. 1989 öszétől megszünt az orosz nyelv kötelező tanítása az oktatási intézményekben. 1990. március 12én elkezdődött a Magyarországon állomásozó szovjet csapatok kivonása az országból. 1990 végén megszünt a Szovjet Irodalom címü folyóirat. Magyarországon a politikai események következtében nemcsak szovjet-, hanem oroszellenes hangulat uralkodott. Divatossá vált mindenről, ami orosz, vagy ami valamilyen formában köthető volt a Szovjetunióhoz, a szovjet vagy az orosz kultúrához, lenézően és ellenségesen viszonyulni. Habár az új Magyarország kultúrpolitikája nyíltan nem tiltotta az orosz irodalom kiadását - hiszen hivatalosan az országba végre eljött a szabadság időszaka -, viszont a nyilvánvaló nyugati orientáció kizárta a kortárs orosz irodalom magyarországi terjesztését és népszerűsítését. Mindez a kortárs orosz irodalom iránti érdeklődés rohamos, szinte egyik napról a másikra bekövetkezett hanyatlásához vezetett. Sem a könyvkiadók, sem a folyóiratok szerkesztőségei nem voltak hajlandók orosz irodalmi műveket közölni, az oroszból fordító műfordítóknak gyakran szégyent (időnként akár megaláztatást is) kellett érezniük a szerkesztők elött, ha mégis arra vetemedtek, hogy orosz irodalmi mű fordítását ajánlják megjelentetésre. A magyarországi ruszisták ugyanakkor joggal szemlélték értetlenül a helyzetet, hiszen az orosz irodalommal szemben tanúsított ilyen mértékủ elutasítás éppen akkor következett be, amikor az oroszországi irodalmi folyamatokban jelentős változások történtek. A valóban unalmas és sekélyes hivatalos szovjet irodalmat új, friss, korábban sosem látott irodalmi művek váltották fel, és mint ismeretes, Oroszországban az 1990-es évek ennek az új irodalomnak, a posztmodernnek a 
felvirágzását hozták el. Valójában mindegy is, hogyan látjuk ma az úgynevezett „másik irodalmat", az orosz noir irodalmat, az orosz posztmodernt vagy más korabeli irodalmi irányzatokat, mindegy, hogyan értékeljük ma esztétikai értékeiket vagy az általuk közvetített morális értékeket, azt mindenképpen el kell ismernünk, hogy ezek az irányzatok megtanították újszerủen látni az irodalmat, újszerủen befogadni a müveket, újszerüen közelíteni olyan alapvető irodalomtudományi kérdésekhez, mint amilyen például az irodalmi mủ és a valóság egymáshoz való viszonya, a szöveg mibenléte, a narráció problémái, vagy akár az írónak a társadalomban betöltött szerepe. Amikor a magyarországi könyvkiadók és folyóiratok az 1990-es években megtagadták a kortárs orosz irodalmi müvek publikálását, egyúttal azt is visszautasították, hogy megismerjék az új orosz irodalmi folyamatokat és jelenségeket, következésképpen a magyar kultúrpolitika azt követően, hogy a nyugati határainkon ledöntötte a vasfüggönyt, elképesztő módon, a szabadság nevében, új vasfüggönyt húzott fel a keleti határon.

\section{3, A 2000-es évek: a posztmodern irodalom befogadásának dominanciája}

Az 1990-es évek végére a fent leírt helyzet bizonyos mértékig fokozatosan megváltozni látszott: megjelent néhány, az orosz posztmodern irodalmat képviselő mű (Viktor Jerofejev $A z$ orosz széplány címü regénye és az Élet egy idiótával című elbeszéléskötete, Viktor Pelevin A rovarok élete címü könyve) magyar fordításban. E folyamatnak, meglátásom szerint, két alapvető oka volt.

a) A magyar kiadók, miután értesültek róla, hogy az orosz posztmodern szerzők jelentős sikereket értek el Nyugat-Európában, úgy döntöttek, hogy „kockáztatnak” és megjelentetnek néhány, nyugaton nagy port kavart kortárs orosz irodalmi müvet. A magyarországi könyvkiadásban, mondhatni, ismét a régi recept szerint jártak el: mintha csak visszatértek volna a 19. század végi, 20. század eleji gyakorlathoz, amikor az orosz irodalom remekműveit nem oroszból, hanem elsősorban németből és franciából fordították magyarra. Az 1990-es évek végén a magyar könyvkiadók mintegy Németországon és Franciaországon keresztül hozták be Magyarországra a nyugaton sikeressé vált kortárs orosz szerzőket - habár, természetesen, a megjelentetett műveket közvetlenül oroszból fordíttatták.

b) Magyar ruszisták (irodalomtörténészek és müfordítók) maroknyi csoportja, amely az 1990-es években, vagyis az orosz kultúrától és irodalomtól való elhatárolódás időszakában sem adta fel, hogy orosz irodalommal (többek között kortárs orosz irodalommal is) foglalkozzon, minden politikai, társadalmi és kulturális ellenállást leküzdve mégiscsak áttörte valamelyest az orosz kultúrát és irodalmat illető, előítéletekből rakott falat.

A kortárs orosz irodalom magyarországi kiadásában bekövetkezett jelentős változás az 1990-es évek végére nyúlik vissza. Előbb 1995-ben az Osiris Kiadó gondozásában megjelent Se apák, se fiúk: Poszt szovjet dekameron címmel egy novelláskötet, amely bár meglehetősen vegyes válogatás, mégiscsak adott valamely betekintést a kortárs orosz irodalmi folyamatokba. Aztán 1997-ben a Jelenkor júliusi-augusztusi számában jelent 
meg az új orosz irodalomból terjedelmes válogatás (benne olyan művek fordításával, mint Vlagyimir Szorokin Átutazóban címü elbeszélése, Dmitrij Galkovszkij Végtelen zsákutca címü könyvének részletei, vagy az orosz posztmodern egyik alapvető elméleti írása, Mihail Epstejn Az orosz posztmodern értelme és eredete címü esszéje), valamint hazai ruszisták tanulmányai az orosz posztmodern irodalomról. Ezt követően a Jelenkor 1999-es évfolyamának számaiban sorozat indult Utazás Leningrádból Szentpétervárra címmel, amelyben hat posztmodern szerző (Szergej Dovlatov, Jevgenyij Popov, Tatyjana Tolsztaja, Viktor Pelevin, Dmitrij Galkovszkij, Vlagyimir Szorokin) írásai jelentek meg olyan tanulmányok kíséretében, amelyek a felsorolt írók művészetének tárgyalásán kívül képet adtak az 1980-1990-es évek orosz irodalmi folyamatairól is. ${ }^{16}$

Ettől kezdődően, a 2000-es évek folyamán megjelentek magyar fordításban Szergej Dovlatov válogatott kisregényei, Viktor Jerofejev addig írt szinte minden jelentősebb írása, Viktor Pelevin és Vlagyimir Szorokin művei, Jevgenyij Popov regénye és novelláskötete, Tatyjana Tolsztaja regénye és elbeszéléskötete, Vaszilij Akszjonov három regénye, Borisz Akunyin híres detektívregény-sorozata, Olga Szlavnyikova két regénye, Gyina Rubina két könyve, Ergali Ger, Grigorij Rjazsszkij és Jurij Bujda egy-egy könyve - és még sok más kortárs orosz mü is.

Külön fejezetet érdemel a kortárs orosz irodalom magyarországi befogadásában Ljudmila Ulickaja könyveinek kiadása. Első munkája, amelynek magyar fordítása készült, 2003-ban jelent meg a Magvető Kiadónál, és attól kezdve sorra jöttek ki regényei, kisregényei és elbeszélései, mégpedig a magyarországi viszonyokhoz képest nagy példányszámban (az első kiadások tízezer példányban). Ulickaja hihetetlen népszerüségnek örvend mind a mai napig, műveinek újabb és újabb kiadásai készülnek, művészetéről tudományos munkák, disszertációk, diplomamunkák, kritikai írások születnek - vagyis egyértelműen a magyarországi irodalmi élet szerves részévé vált. Olyan irodalmi sikerekkel büszkélkedhet Magyarországon, amelyet joggal irigyelhet sok hazai vagy magyarra fordított más külföldi szerző is.

\section{4, A 2010-es évek: az „új realizmus” irodalmának recepciója}

Az 1990-es évek végén, 2000-es évek elején Oroszországban heves irodalmi vita bontakozott ki, amelyet olyan írók és irodalomkritikusok fiatal nemzedéke kezdeményezett, akik arról beszéltek, hogy az orosz irodalmi életben felborult az egyensúly, és túlsúlyba kerültek a posztmodern szövegkonstrukciók, szójátékokra, rejtett és nyílt irodalmi idézetekre, allúziókra, ironikus megközelítésekre, paródiákra épülő művek, amelyek kiszorítják a hagyományos elbeszélői formákra alapozó munkákat, miközben az olvasóközönség részéről egyre nagyobb igény mutatkozik a fordulatos cselekményvezetést, hagyományos elbeszélői módot, plasztikusan megformált, „hús-vér” szereplőket és a valós társadalmi problémák bemutatását megvalósító irodalmi művekre.

${ }^{16}$ GoRetity József, Utazás Leningrádból Szent-Pétervárra 1-6, Jelenkor, 1999/1, 52-56; 1999/3, 277 279; 1999/4, 380-383; 1999/6, 621-625; 1999/9, 911; 1999/12, 1242-1245. 
Az 1990-es évek végétől az oroszországi irodalomkritikában (mindenekelőtt a fiatal kritikusokból álló PoPuGan csoportban) egyre többet kezdték el használni az „új realizmus" terminust, elsősorban az abban az időben meglehetősen fiatal nemzedékhez tartozó szerzők írásai kapcsán. A Novij Mir című folyóirat 2001-es évfolyamának decemberi számában egy fiatal író és irodalomkritikus, Szergej Sargunov megjelentette provokatív esszéjét, A gyász tagadása címüt, ${ }^{17}$ amelynek sokat sejtető címe egyértelmúen az orosz posztmodern irodalom egyik programadó írásának, Viktor Jerofejev Halotti beszéd a szovjet irodalom felettjének címével polemizált. ${ }^{18}$ Sargunov az orosz „új realizmus” kiáltványává vált írásában azt fejtegeti, hogy véleménye szerint az 1990-es évek orosz irodalmi folyamata sikertelen volt, az orosz posztmodern zsákutcába jutott (a szerző szó szerint a posztmodern agóniájáról beszél), az orosz irodalom jövőjét pedig a klasszikus orosz irodalom legjobb hagyományait felelevenítő realista irányban határozza meg.

A realizmusról („új realizmusról”) szóló vita 2010-ben újra fellángolt, ezúttal a Lityeraturnaja Gazetában, abban az irodalmi hetilapban, amelynek akkori föszerkesztöje, Jurij Poljakov maga is a realista irodalom elkötelezett képviselője. Az új vita ürügyéül az a tény szolgált, hogy az „új realizmushoz" kapcsolódó írók a 2000-es évek folyamán ismertté, népszerüvé és sikeressé váltak nemcsak Oroszországban, hanem külföldön is: a legjelentősebb irodalmi folyóiratoknál és könyvkiadóknál jelentek meg müveik, számos nyelvre lefordították őket, komoly irodalmi díjakat nyertek el.

Sajnálatos módon az orosz „új realizmus” irányzatáról Magyarországon csak kevesen tudtak, képviselőikről nem írtak a hazai lapok, műveiket nem fordították magyarra. Ily módon a 2010-es évekre a kortárs orosz irodalom magyarországi recepciójára ugyanaz az egyoldalúság volt jellemző, mint amiről az „új realisták” a 2000-es évek elején Oroszországban írtak: az orosz posztmodern irodalom teljes mértékben kiszorította az új nemzedék írásait, egyáltalán, a realista irányultságú irodalmat.

A helyzet akkor kezdett némiképp változni, amikor a Tiszatáj címü folyóiratban tanulmány jelent meg $A z$ orosz „új realizmus” értelme és eredete címmel, amely egyfelől részletes ismertetést tartalmazott az orosz posztmodern szerzők és az „új realisták” között kialakult vitáról, másfelől bemutatásra került az új irányzat néhány jelentősebb képviselőjének munkássága. ${ }^{19} \mathrm{~A}$ tanulmány megjelenését követően elkezdődött az „új realisták" magyarországi kiadása: magyar fordítása látott napvilágot többek között Oleg Pavlov, Zahar Prilepin, Roman Szencsin regényeinek. Ezt követően novellaválogatás jelent meg Forró vodkával teli bakancs (Kairosz Kiadó, 2018) címmel, amelyben a már említett szerzők művein kívül olyan „új realista” írók elbeszélései kaptak helyet, mint Szergej Sargunov, Alekszej Ivanov, Alekszandr Karaszjov, Andrej Gelaszimov,

\footnotetext{
${ }^{17}$ Szergej SARgunov, Otricanyije traura, Novij Mir, 2001/12. http://www.zh-zal.ru/novyi_mi/2001/12/ shargunov.html (Letöltés ideje: 2020. július 20.)

${ }^{18}$ Viktor Jerofejev, Halotti beszéd a szovjet irodalom felett, ford. Gereben Ágnes, Nagyvilág, 1990/1, 122-129.

${ }^{19}$ Goretity József, Az orosz „új realizmus” értelme és eredete, Tiszatáj, 2013/8, 22-33.
} 
Gyenyisz Gucko. A realista irányultságú, de nemzedéki okok miatt nem az ifjú „új realisták" csoportjához tartozó szerzők közül Jurij Poljakov regényei (Gödölye tejben, Szökni szeretnék, Bukottak égboltja, Demagrád) és fergeteges komédiája, a Homo Erectus jelentek meg magyarul, és váltak népszerüvé az olvasók körében.

A „posztmodernek” és az „új realisták” vitájával kapcsolatban annyit mindenképpen meg kell jegyezni, hogy a jelenlegi oroszországi irodalmi élet tapasztalatai azt mutatják, hogy egyfelől a realista beállítottságú szerzők csak abban az esetben tudnak sikeresek lenni, ha figyelembe veszik a posztmodern eredményeit is: a 21. századi realizmus csak akkor válhat hosszú távon is életképessé, ha túllép a valóságábrázolás és/ vagy valóságtükrözés elavult koncepcióján, ha túllép a dokumentarizmuson és képes a posztmodern prózapoétikai eljárásokat alkotó módon alkalmazni a saját, „új realista" művekben. Másfelől, a posztmodern képviselőinek akkor van esélyük a túlélésre, ha képesek belátni, hogy az olvasók nem szövegkonstrukciókat, szójátékokat, ironikus citátumokat akarnak olvasni, amikor regényt vesznek a kezükbe, hanem izgalmas történeteket, plasztikusan megformált, pszichológiai szempontból is következetesen felépített szereplőkkel, mai problémákkal, hiteles emberi helyzetekkel - vagyis mindazzal, amit az „új realisták” hirdetnek.

A posztmodern és az „új realista” eljárások és szemléletmódok ilyesféle sikeresen megalkotott szintézisére látni törekvéseket a kortárs orosz irodalomban. Ilyen müveknek gondolom például Marina Sztyepnova Lazar asszonyai, Alekszandr Tyerehov A Kőhíd, Jevgenyij Vodolazkin Laurosz, Guzel Jahina Zulejka kinyitja a szemét vagy Narine Abgarjan Égből hullott három alma címü könyveit, amelyek a magyar müfordítóknak és könyvkiadóknak köszönhetően már magyarul is olvashatók.

\section{Könyvkiadói szempontok}

Ha megpróbáljuk feltérképezni, mi alapján döntenek a magyarországi könyvkiadók abban, hogy mely kortárs orosz irodalmi műveket jelentessék meg, a következő főbb szempontokat sorakoztathatjuk fel:

a) Mivel a könyvkiadók piaci alapon működnek és profitorientáltak, mindenekelőtt azok a művek kerülnek előtérbe, amelyeknek kiadását a kiadók előre nyereségesnek vélik. Ennek elözetes megállapítása - több ok miatt is - szinte lehetetlen. E vonatkozásban az orosz irodalom magyarországi recepciója sajátos helyzetben van. Nem müködik vele kapcsolatban az a recept, amely, mondjuk, az angol nyelvü irodalomnál beváltnak látszik. Bár voltak olyan kiadói kísérletek, hogy az orosz könyvpiacon nagy példányszámban megjelentetett és eladott orosz populáris irodalom termékeit (krimit, női irodalmat) az anyagi siker reményében magyarul is megjelentessenek, ezek a kísérletek szinte kivétel nélkül kudarcba fulladtak. Jó példa lehet erre Irina Gyenyezskina Adj nekem! címü, jobbára kamasztörténeteket meglehetős szabadszájúsággal elmesélő, Oroszországban a megjelenését követően (2002) bestsellerré vált 
könyve, vagy a népszerű krimi író, Polina Daskova két, magyarul olvasható regénye (A téboly könnyed léptei, Magzatvér), amelyek - minden várakozás ellenére - bukást jelentettek a magyar könyvpiacon. E tendencia alól mindössze Dmitry Glukhovsky Metró-sorozata jelentett kivételt, amely - az egész Metró-univerzummal és a hozzá kapcsolódó számítógépes játékokkal együtt - nagy népszerüségnek örvend Magyarországon is. (Jellemző, persze, hogy a szerző ragaszkodik hozzá, hogy neve kifejezetten az angol átírásnak megfelelően szerepeljen a borítón.) Mindebből az a következtetés vonható le, hogy Magyarországon azok a kortárs irodalmi művek váltak népszerüvé, amelyek mély tartalommal, intellektuális élménnyel, valódi esztétikai értékekkel örvendeztették meg az olvasót. Az orosz irodalommal szemben támasztott magyar olvasói elvárások azt látszanak megfogalmazni, hogy az orosz irodalmi mü minden szempontból legyen igényes és tartalmas.

b) Az anyagi megfontolások miatt azok a művek kerülnek előtérbe a magyarországi könyvkiadásban, amelyeket hazai, de még inkább oroszországi (például az Insztyitit Perevodától vagy a Prohorov Alapítványtól származó) könyvkiadási és/vagy fordítói támogatásban részesülnek. Ahhoz azonban, hogy a magyar kiadás rentábilis lehessen, gyakran ezek a támogatások sem elegendők, így a kiadók még az esetleges támogatás reményében is kénytelenek elállni egy-egy könyv megjelentetésétől.

c) A magyarországi könyvkiadók egyik legfontosabb tájékozódási pontjává manapság a különféle nemzetközi könyvfesztiválok és könyvvásárok váltak. E rendezvényeken - túl azon, hogy az olvasóközönség a hatalmas könyvkínálat mellett találkozhat kedvenc külföldi szerzőivel is - lehetőség nyílik a könyvkiadók és könyvügynökségek képviselöinek találkozására, ahol a szerzők ügynökei „házalnak” szerzőikkel és könyveikkel. A könyvfesztiválok és könyvvásárok egyre inkább a könyvügynökök fesztiváljává válnak, ahol a könyvkiadók sokkal inkább egy adott könyvügynök rábeszélőképessége, semmint a kínált könyv valós értékei (vagy értéktelensége) alapján döntenek a kiadói jogok megvásárlásáról.

d) A kiadásról szóló döntés alapjául még ma is gyakran szolgálnak azok az információk, hogy mely könyvek váltak már sikeressé a „nagy” európai nyelvterületeken (angolon, németen, francián, újabban a kínain). Ezekben az esetekben tulajdonképpen a már említett régi recept, a „németből fordítani” módszere áll elő. Ez a kiadói megfontolás sok esetben működik (Ulickaja könyveinek magyarországi kiadására például az után kerülhetett sor, miután kiderült, hogy Franciaországban is, Olaszországban is, majd Oroszországban is rangos irodalmi díjakat kapott), de garanciát a sikerre egyáltalán nem jelent, és más esetekben teljes zsákutcába vezethet: egyáltalán nem biztos ugyanis, hogy ha valamely nemzeti irodalom „befogad” egy orosz irodalmi müvet, akkor a magyar irodalmi közeg is törvényszerüen befogadja azt (lásd ezzel kapcsolatban a tanulmány elején megidézett Itamar Even-Zohar-féle álláspontot). Zahar Prilepin Szanyka címü regénye, amely magyarul Mert mi jobbak vagyunk címmel jelent meg, a hazai könyvpiacon majdhogynem észrevétlen maradt, annak ellenére, hogy - a szerző saját bevallása szerint is - ez az orosz belpolitikai viszályokról, 
a radikálisok tüntetéseiről szóló regény hozta meg neki a hazai és nemzetközi ismertséget: számos nyelvre lefordították, hazai és külföldi irodalmi díjakat kapott érte. Meggyőződésem, hogy első magyar Prilepin-könyvként érdemesebb lett volna mind a témája (csecsen háború), mind a bonyolultabb művészi megvalósítása miatt egy másik regényét, a Patológiák címüt megjelentetni, amely ugyan nem kapott akkora oroszországi és külföldi publicitást, mint a Szanyka, viszont jobban illeszkedett volna a magyar irodalmi közegbe. S ezzel elkerülhető lett volna, hogy a világszerte egyik legismertebb kortárs orosz szerző nálunk majdhogynem az ismeretlenség homályába vesszen.

e) Fontos döntési szempont lehet, hogy egy adott szerző vagy könyv milyen irodalmi díjakat kap. E vonatkozásban a nemzetközi díjak odaítélése lehet, hogy biztosabb támpontot adhat, viszont - a dolog természetéből fakadóan - a magyar könyvkiadás számára mindig megkésettséget jelenthet: ahhoz, hogy egy orosz könyv nemzetközi díjat kapjon, előbb meg kell jelennie más idegen nyelveken, és csak ezt követően kerülhet sor a magyar fordításra és kiadásra. Ami pedig az oroszországi irodalmi díjakat illeti, sokban nehezíti a reális tájékozódás lehetőségét, hogy egy 2009-ben elkészült hivatalos lista szerint Oroszországban 336 irodalmi díj létezik. ${ }^{20}$ A díjak nyilvánvalóan különböző ízlésvilágokat takarnak, amelyeknek értékrendje nem feltétlenül esik egybe a magyarországi könyvkiadók értékrendjével és érdekeivel.

f) A müvek esztétikai minősége. Sajnálatos módon ez a szempont nemcsak a jelen felsorolásban került az utolsó helyre, hanem a kiadók döntési mechanizmusában is: minden esztétikai értékkel kapcsolatos szempontot felülírhat az eladhatóság, a jövedelmezőség szempontja. Pedig az esztétikai minőség figyelembe vétele szolgálná a leginkább a fordításirodalom hosszú távú érdekeit, csak a magas esztétikai értékekkel bíró orosz irodalmi művek (jó minőségü) magyar fordításainak van esélyük a maradandóságra. Úgy vélem, a kiadók döntési mechanizmusába e szempont jobb érvényesítése érdekében a jelenleginél intenzívebben be kellene vonni azoknak a szakembereknek (orosz irodalommal foglalkozó irodalomtörténészeknek és müfordítóknak) véleményét, ajánlásait, akik foglalkozásuk, szaktudásuk okán több-kevesebb rálátással bírnak a kortárs orosz irodalmi folyamatokra és képesek a művek esztétikai értékének reális megítélésére.

\section{Összegzés}

Mindezek mellett ugyanakkor elmondható, hogy Magyarországon a kortárs orosz irodalom kiválóan van reprezentálva, és bármilyen furcsán is hat, talán jobban, mint a kortárs angol, német, francia, olasz, spanyol irodalom, nem is beszélve a környezö

${ }^{20}$ Az Orosz Állami Könyvtár hivatalos adata. A listát M. Je. BABICseva állította össze. https://olden.rsl.ru/ru/s3/s331/s122/s1223629/s12236293630/ (Letöltés ideje: 2020. július 20.) 
országok (Ausztria, Lengyelország, Csehország, Szlovákia, Ukrajna, Románia, Bulgária, Szerbia, Horvátország, Szlovénia) irodalmairól. És ez, természetesen, a magyar olvasóközönség orosz irodalom iránti töretlen érdeklődését mutatja.

\author{
Goretity József \\ egyetemi docens \\ Debreceni Egyetem \\ goretity.jozsef@arts.unideb.hu
}

What to Translate?

Hungarian Reception of Contemporary Russian Literature from a Translator's Point of View

\begin{abstract}
Abstact: The study focuses on the reception of Russian literature, more precisely contemporary Russian literature. The author of the article examines the question whether and how much a translated literary work can become an integral part of the recipient culture and what are those fundamental aspects based upon which a national culture, as a recipient, "chooses" certain works of a foreign literature to be translated. After outlining the history of Hungarian reception of translated Russian literature the paper introduces in detail the last 35 years of Hungarian reception of Russian literature, including the well-differentiated periods and the aspects of reception. The paper aims to answer the question fundamental in Russian-Hungarian translation as well: 'What to translate?'
\end{abstract}

Keywords: the connection between source language and target language, "deficient supply" and "recognition", Hungarian reception of Russian literature, contemporary Russian literature, literature of perestroika, Russian postmodern literature, the literature of "new realism"

DOI: 10.37415/studia/2020/1-2/8-21.

Open Access: Creative Commons Attribution 4.0 International (CC BY 4.0) (c) (i) 